\title{
Use of RAPD Molecular Markers on Differentiation of Brazilian and Chinese Ganoderma lucidum Strains
}

\author{
Leonardo do Nascimento Rolim ${ }^{1 *}$, Maria Auxiliadora de Queiroz Cavalcante ${ }^{1}$, Arailde \\ Fontes Urben $^{2}$ and Glaucia Salles Cortopassi Buso ${ }^{2}$ \\ ${ }^{I}$ Departamento de Micologia; Centro de Ciências Biológicas; Universidade Federal de Pernambuco; 50670-420; \\ Recife - PE - Brasil. ${ }^{2}$ Embrapa Recursos Genéticos e Biotecnologia; Prédio de Quarentena e Germoplasma; \\ Parque Estação Biológica, W5 Norte Final; 70770-900; Brasília - DF - Brasil
}

\begin{abstract}
The aim of this work was to analyze the Brazilian and Chinese strains of Ganoderma lucidum with molecular RAPD markers. A similarity matrix was elaborated and the RAPD profiles of $\mathrm{G}$. lucidum strains were also compared to two other Ganoderma spp: G. applanatum and G. lipsiense in order to produce genetic similarity among the species. Based on the primers used, it was possible to determine that the Brazilian strains and Chinese strain CC-22 are alike. The method and the primers selection showed to be appropriate for the genetic identification of G. lucidum strains, enabling them to be improved and used in research, as well as in the world market.
\end{abstract}

Key words: Ganoderma lucidum, genetic diversity, RAPD

\section{INTRODUCTION}

Ganoderma lucidum (Fr.) Karst. (Ganodermataceae) is a very popular basidiomycete on the traditional Chinese medicine, and is also used in other countries as Japan and the United States as food supplement. In Brazil, though it is little exploited, this fungus is known as King Mushroom, eaten as food supplement (Mau et al., 2001). Studies carried out with G. lucidum reveal many biological properties, such as anti-tumor, anti-inflammatory, antiviral (anti-HIV) and antibacterial activity. Its pharmacological effects have been studied in the treatment against many human diseases such as hepatitis, hypertension, heart problems, arthritis, bronchitis, tumors, diabetes, insomnia, and others (Kim, 1987; Nogami, 1987; Kim et al., 1995; El-
Mekkawy et al., 1998; Eo et al., 1999; Wasser and Weis, 1999; Hsieh et al., 2005; Lakshmi et al., 2006; Tang et al., 2006; Chu et al., 2007; Li et al., 2007; Zhu et al., 2007).

The taxonomy of the genus is traditionally based on the morphological characteristics. Though they are really useful for differing species, there are still difficulties for distinguishing the close groups such as the populations or strains of the same species. According to Zheng et al. (2007), environmental factors, variability, interhybridization and morphological propensity make the accurate identification hard for Ganoderma species. However, the new techniques using molecular markers has turned easy the identification not only for Ganoderma species, but also for other organisms which has the same taxonomic difficulties. The use of DNA as

*Author for correspondence: leonardorolim@yahoo.com.br 
identification tool allowed to differentiate the subgroups, as the various G. lucidum strains, making easy to distinguish mainly the commercial strains and strains of industrial interest (Zheng et al., 2007).

Several techniques for molecular studies have been used for analyzing the genetic diversity in basidiomycetes, such as isoenzymes (Lan et al., 1998), AFLP (Amplified Fragment Length Polymorfism) (Qi et al., 2003), RFLP (Restriction Fragment Length Polymorfism) (Park et al., 1996), ITS (Internal Transcribed Spacers) (Kindermann et al., 1998) and RAPD (Random Amplified Polymorphic DNA) (Wang et al., 2003). Among these techniques, RAPD is still one of the cheapest and quickest methods for accessing the variability at DNA level, being especially useful on intraspecific analysis. These markers have the advantage of amplifying both regions of the genome which may be transcript/translated, and non-coding regions. This is important when the objective is to evaluate the variation along the biggest part of the species genome (Williams et al., 1990; Ferreira and Grattapaglia, 1996; Ro et al., 2007). On the other hand, RAPD has limitations for its low experimental reproducibility, although this problem may be overcome with the use of many primers and with more strict criteria in analyzing the results (Carvalho and Vieira, 2001).

This work aimed to select the RAPD molecular markers for Ganoderma lucidum, evaluating the genetic similarity pattern between the Brazilian and the commercial Chinese strains.

\section{MATERIAL AND METHODS}

\section{Ganoderma lucidum strains}

Four G. lucidum strains were used: two Brazilian (identified as CC-144 and CC-157) and two Chinese commercial strains (CC-22 and CC-63) (Table 1). These are available in the Germplasm Bank of Mushrooms for Human Use of Embrapa Genetic Resources and Biotechnology (Brasilia, DF, Brazil). Besides these, the samples of two other Ganoderma strains were used: $G$. applanatum and $G$. lipsiense (originated from China), in order to establish the genetic comparisons at genus level.

Table 1 - Origin of the G. lucidum strains used in the study.

\begin{tabular}{ccc}
\hline Strain & Local & Date of Collection \\
\hline CC-22 & China & $19 / 02 / 2004$ \\
CC-63 & China & $10 / 02 / 2006$ \\
CC-144 & Brasília, Brazil & $10 / 02 / 2006$ \\
CC-157 & São Paulo, Brazil & $25 / 01 / 2006$ \\
\hline
\end{tabular}

\section{DNA extraction}

Fungi were taken from the matrix tubes and grown in Petri dishes containing PDA (20\% Potato, 2\% Dextrose, $1.5 \%$ Agar), for seven days in complete darkness at $28^{\circ} \mathrm{C}$ and RU $82 \%$. Each isolate was transferred to PDA liquid medium at $28^{\circ} \mathrm{C}$ for two weeks. The medium with mycelium was centrifugated at 3,000 rpm for 10 minutes, washed with sterilized water and softly pressed on filter paper. Strains were transferred to Eppendorf tubes of $1.5 \mathrm{~mL}$ in which they were macerated in liquid nitrogen, treated with $1 \mathrm{~mL}$ of extraction buffer solution (1M Tris-HCl pH 8.0, 0.5M EDTA pH 8.0, 10\% SDS, 5M NaCl) (Raeder and Broda, 1985 ) and incubated for one hour at $65^{\circ} \mathrm{C}$. Then a phenolic solution was added, softly mixing the phases and centrifuged at $10,000 \mathrm{rpm}$ for 15 minutes. The aqueous phase was transferred to new Eppendorf tubes with a solution of chlorophorm:isoamilic acid (24:1), mixed and centrifuged as above. The supernatant was taken in the tubes with one volume of $\mathrm{NaCl}(1 \mathrm{M})$ and two volumes of ethanol (chilled to $-20^{\circ} \mathrm{C}$ ). After centrifugation at $15,000 \mathrm{rpm}$ for 15 minutes, the supernatant was disposed and the precipitate was washed with ethanol $(70 \%)$. The microtubes were dried and the material was resuspended in $20 \mu \mathrm{L}$ of TE buffer solution (1M Tris- $\mathrm{HCl} \mathrm{pH} 8.0,0.5 \mathrm{M}$ EDTA pH 8.0). The samples had their DNA concentration quantified on agarose gel $1.5 \%$ and stocked up at $-80^{\circ} \mathrm{C}$.

\section{RAPD analysis}

The DNA from the strains was amplified through RAPD according to Williams et al. (1990), using 48 arbitrary primers from Operon Technologies Inc. (Alameda, CA, USA), with average size of 10 bases: OPAB-02, OPAB-14, OPAB-18, OPAB-19, 
OPA-02, OPA-05, OPA-07, OPA-11, OPA-12, OPA-17, OPA-18, OPB-02, OPB-05, OPB-06, OPB-09, OPB-10, OPB-11, OPC-02, OPC-18, OPC-19, OPD-02, OPD-04, OPD-07, OPD-20, OPE-04, OPE-06, OPE-08, OPF-01, OPF-02, OPF-06, OPF-08, OPF-12, OPG-04, OPG-15, OPH-12, OPO-15, OPO-19, OPR-02, OPR-08, OPR-09, OPR-10，OPR-12，OPR-19，OPR-20, OPU-01, OPV-08, OPW-18 and OPX-20. The reactions were carried out in a thermocycler PTC100 (MJ Research Thermal Cycler), with the use of a program following the due steps: (1) DNA melting at $96^{\circ} \mathrm{C}$ for 3 minutes and (2) at $92^{\circ} \mathrm{C}$ for 1 minute; (3) primer annealing at $35^{\circ} \mathrm{C}$ for 1 minute; (4) molecule extension with Taq polymerase (provided by Amersham Pharmacia Biotech) at $72^{\circ} \mathrm{C}$ for 2 minutes; (5) 40 cycles following steps 2-4; (6) final step of the 5 minute extension at $72^{\circ} \mathrm{C}$ in order to finalize the amplified products. For amplifying the samples, the following compounds were used for a total volume of $13 \mu \mathrm{L}: 3.0 \mu \mathrm{L}$ genomic DNA at 3.00 $\mathrm{ng} / \mu \mathrm{L} ; 4.92 \mu \mathrm{L}$ Milli-Q water; $1.3 \mu \mathrm{L}$ buffer solution 10X for Taq DNA polymerase; $1.04 \mu \mathrm{L}$ dNTP $2.5 \mathrm{mM} ; 1.04 \mu \mathrm{L}$ BSA $2.5 \mathrm{mM} ; 1.5$ primer $10 \mathrm{ng} / \mu \mathrm{L}$ and $0.2 \mu \mathrm{L}$ Taq DNA polymerase. The samples of amplified DNA were put on agarose gel $1.5 \%$ (120 volts for $4 \mathrm{~h})$, on TAE buffer solution $1 \mathrm{X}$, using the $1 \mathrm{~kb}$ DNA ladder molecular mass marker (Life Technologies, Cergy-Pontoise, France) as reference. This gel was stained with etide bromide and observed through transilluminator under UV light and photographed with Stratagene's camera for documentation Eagle Eye II. Three repetitions of the RAPD were made, the first only with $G$. lucidum strains, other similar, with the addition of G. applanatum, and a third one, using G. lipsienses.

\section{Post-RAPD Analysis}

The primers which presented better band pattern were used for building a similarity index among the pairs of isolates, based on the Jaccard coefficient (Sj,j) (Dias, 1998), designating 1 for the presence of band and 0 for the absence of band in the gel. The Jaccard coefficient (Sij) among the pairs of strains is given by $\mathrm{Sij}=\mathrm{a} /(\mathrm{a}+\mathrm{b}+\mathrm{c})$, in which "a" is the number of positive marks between the $i$ and $j$ isolates, while " $b$ " and "c" are the number of loci present in only one of the isolates. Sij values close to 1.0 indicate high genetic similarity among the strains. In order to represent graphically the genetic divergence patters, the similarity matrix was submitted to a group analysis like UPGMA (Unweighted PairGroup Method Analysis), using the NTSYS program (Numerical Taxonomy and Multivariate Analysis System) version 2.2. In this method, the criteria used for generating the groups is the average of the distances among all the pairs of items from each group as the denomination itself informs. The inter-group distance is the average of the paired distances of members from both groups (Dias, 1998).

The binary data generated from the observations in gel were used in a computer procedement of resampling on loci (bootstrap). This analysis consists in resampling the loci of the data matrix, with reposition, recalculating the desired statistics several times, testing the stability of the genetic distance obtained through RAPD. Four thousand repetitions were made following the Monte Carlo permutation method. The Monte Carlo permutation method produces simulated dissimilarity values, obtained from data matrix generated through the relocation of the original values of samples (Manly, 1997). Only when the similarity index of the original data (i.e., with no simulation) is significantly higher than the index obtained after permutations, the genetic similarity is considered significant (significance level adopted, $\alpha=0.05$ ). Permutations were made with the software RandMat version 1.0 for Windows.

\section{RESULTS AND DISCUSSION}

All the strains presented positive result on forming the bands on agarose gel, according to the technique for RAPD analysis. From the 48 primers tested, 20 did not amplify or present good amplification pattern. The other 28 primers showed good amplification pattern and presented a total of 512 loci, 323 of them as polymorphs. The average number of loci found was 18.28 , being 11 the minimum and 26 the maximum number of loci per primer (Table 2). 
Table 2 - Relation of numbers of efficient loci and polymorphic loci per primer for RAPD analysis of Ganoderma lucidum strains.

\begin{tabular}{cccc}
\hline Primers & 5' - 3' sequence & number of loci & number of polymorphic loci \\
\hline OPAB-14 & AAGTGCGACC & 17 & 14 \\
OPA-05 & AGGGGTCTTG & 17 & 20 \\
OPA-07 & GAAACGGGTG & 24 & 10 \\
OPA-11 & CAATCGCCGT & 24 & 14 \\
OPA-12 & TCGGCGATAG & 26 & 12 \\
OPB-05 & TGCGCCCTTC & 16 & 16 \\
OPB-06 & TGCTCTGCCC & 21 & 13 \\
OPC-18 & TGAGTGGGTG & 16 & 06 \\
OPC-19 & GTTGCCAGCC & 11 & 17 \\
OPD-04 & TCTGGTGAGG & 19 & 10 \\
OPD-20 & ACCCGGTCAC & 19 & 10 \\
OPE-06 & AAGACCCCTC & 16 & 04 \\
OPE-08 & TCACCACGGT & 17 & 05 \\
OPF-01 & ACGGATCCTG & 12 & 09 \\
OPF-02 & GAGGATCCCT & 17 & 09 \\
OPF-08 & GGGATATCGG & 20 & 10 \\
OPF-12 & ACGGTACCAG & 22 & 10 \\
OPG-15 & ACTGGGACTC & 17 & 04 \\
OPH-12 & ACGCGCATGT & 18 & 10 \\
OPO-15 & TGGCGTCCTT & 17 & 08 \\
OPO-19 & GGTGCACGTT & 15 & 10 \\
OPR-08 & CCCGTTGCCT & 19 & 04 \\
OPR-09 & TGAGCACGAG & 16 & 13 \\
OPR-12 & ACAGGTGCGT & 14 & 12 \\
OPR-19 & CCTCCTCATC & 17 & 17 \\
OPR-20 & ACGGCAAGGA & 24 & 21 \\
OPV-08 & GGACGGCGTT & 23 & 323 \\
OPW-18 & TTCAGGGCAC & 512 & \\
TOTAL & & & \\
\hline
\end{tabular}

The presence and absence of bands were registered on worksheet and used for generating a similarity index. Some bands were not as legible as the other ones, but this did not affect the structure of the generated dendrogram, because only the bands which remained after the repetitions were considered in the study.

The first comparisons made based on the 28 primers indicated that the Brazilian strains CC-144 and $\mathrm{CC}-157$ were the closest ones between themselves, with Jaccard value 0.798. Comparing with the Chinese strains, the group formed by the Brazilian strains was closer to the CC-22 strain (Jaccard $=0.721)$, presenting smaller genetic similarity with the CC-63 (Jaccard $=0.52$ )

The bootstrap analysis, which is used in population genetics in order to evaluate the stability of groups obtained from the genetic distances and to establish the confidence intervals in unfolding the models of variance and populational structure (Weir, 1990; Meyer, 1995; Hillis et al., 1996; Manly, 1997) revealed that CC63 was the only strain whose RAPD showed to be uncertain for determining the genetic similarity among the studied strains. The dendrogram showed that the genetic divergence of CC-63 with the other ones was in the uncertainty area generated by the simulated re-sample analysis (Jaccard 0.43 to 0.6). Result indicated that the point of genetic divergence between the CC-63 and the other strains could oscillate inside the informed area. In the other strains, the genetic similarity and the points of divergence were statistically significant, showing stable result among CC-22, CC-144 and CC-157.

These results showed that the CC-22, CC-144 and CC-157 G. lucidum strains could be differentiated through the RAPD with the primers listed in Table 2. Hseu et al. (1996) studied G. lucidum strains as the RAPD tests and observed the sturdiness of their markers. According to the author, the technique could be applied on different strains and populations of a same species, being of low accuracy when dealing with big taxonomic groups. The RAPD may not be very useful when applied to determine very elaborated phylogenies, evolving big taxonomic groups, but its results are recognized when specific groups are studied (Duncan et al., 1993; Hamelin et al., 1993; Manulis et al., 1994; Laroche et al., 1995; Gomes et al., 2009; Stringari et al., 2009; Gonçalves et al., 2010).

Ro et al. (2007) obtained good results when they used RAPD aiming to differentiate the strains of 
Pleurotus eryngii. The technique has been used in the studies with Verticillium fungicola, with excellent results (Del Carmen et al., 2002; Largeteau et al., 2006) and by other researchers for works with many other organisms, always differentiating very close taxonomic groups (Grazziotin et al., 2005; Muok et al., 2007; Tang et al., 2007; Rajwana et al., 2008; Solouki et al., 2008; Venkatachalam et al., 2008; Tsvelikas et al., 2009). The primers used in this study, however, were not enough to measure with accuracy the genetic distance of the strain CC-63 (Chinese strain), and it is suggested could be use other primers for analyzing or complete the differentiation.
The RAPD profiles of the G. lucidum strains were also compared to G. applanatum and G. lipsiense. The analysis with the 28 used primers resulted in 590 loci for G. applanatum, from which 440 were polymorphs when compared to G. lucidum strains. G. lipsiense revealed 597 loci, 446 of them being polymorphs when compared with the loci of the Ganoderma lucidum strains. These results were compared in order to establish a genetic similarity at genus level among the studied isolates (Fig. 1). Figure 2 shows the distinct RAPD profiles of a sample of isolates in agarose gel.

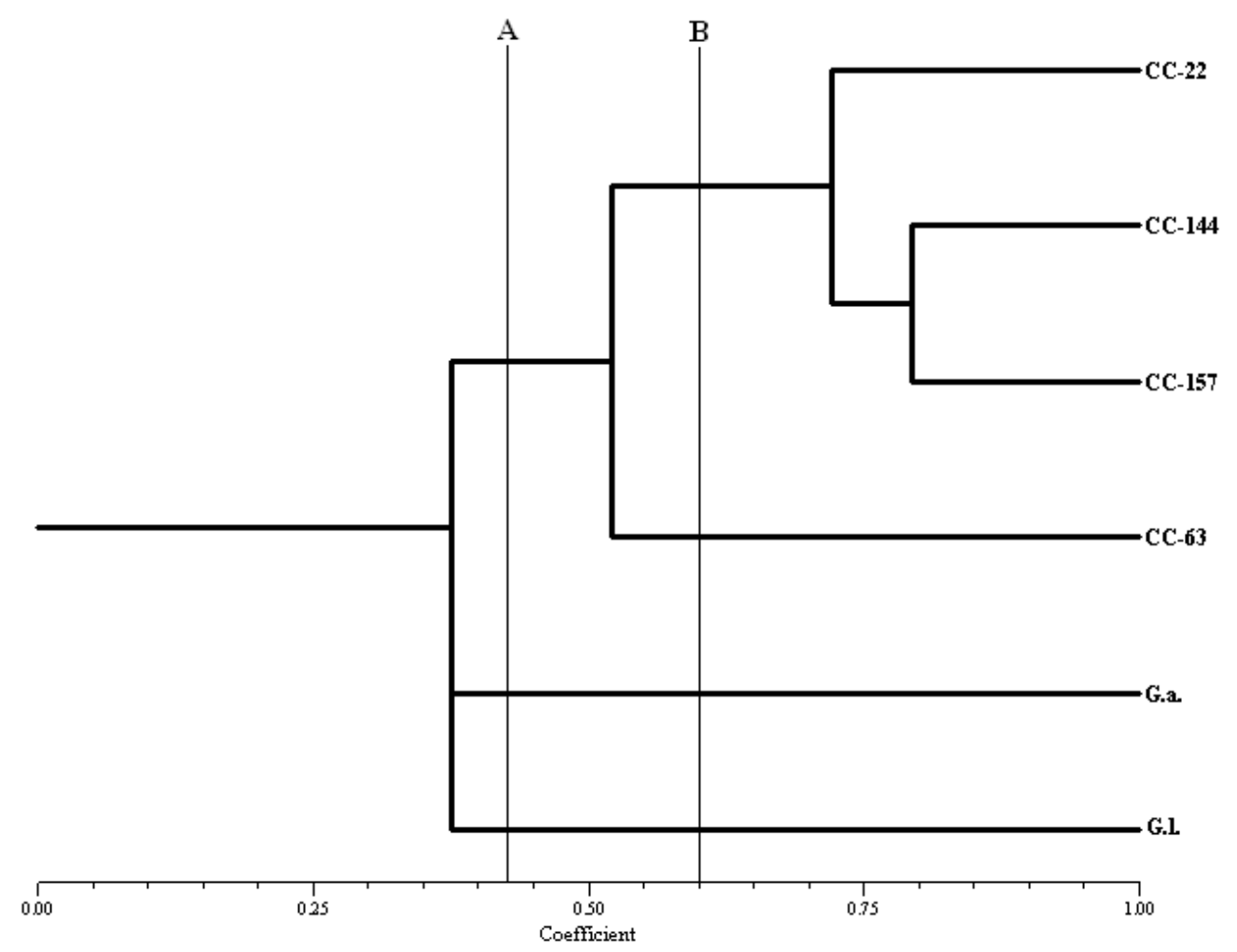

Figure 1 - Dendrogram showing the genetic similarity between the Chinese strains (CC-22 and CC63 ) and the Brazilian strains (CC-144 and CC-157) of G. lucidum, G. applanatum (G.a.) and G. lipsiense (G.1.) after RAPD analysis. The area present between the columns A and $\mathrm{B}$ determine an imprecision gap on genetic analysis, informing that the genetic distance between CC-63 and the other strains may oscillate inside the observed boards. 


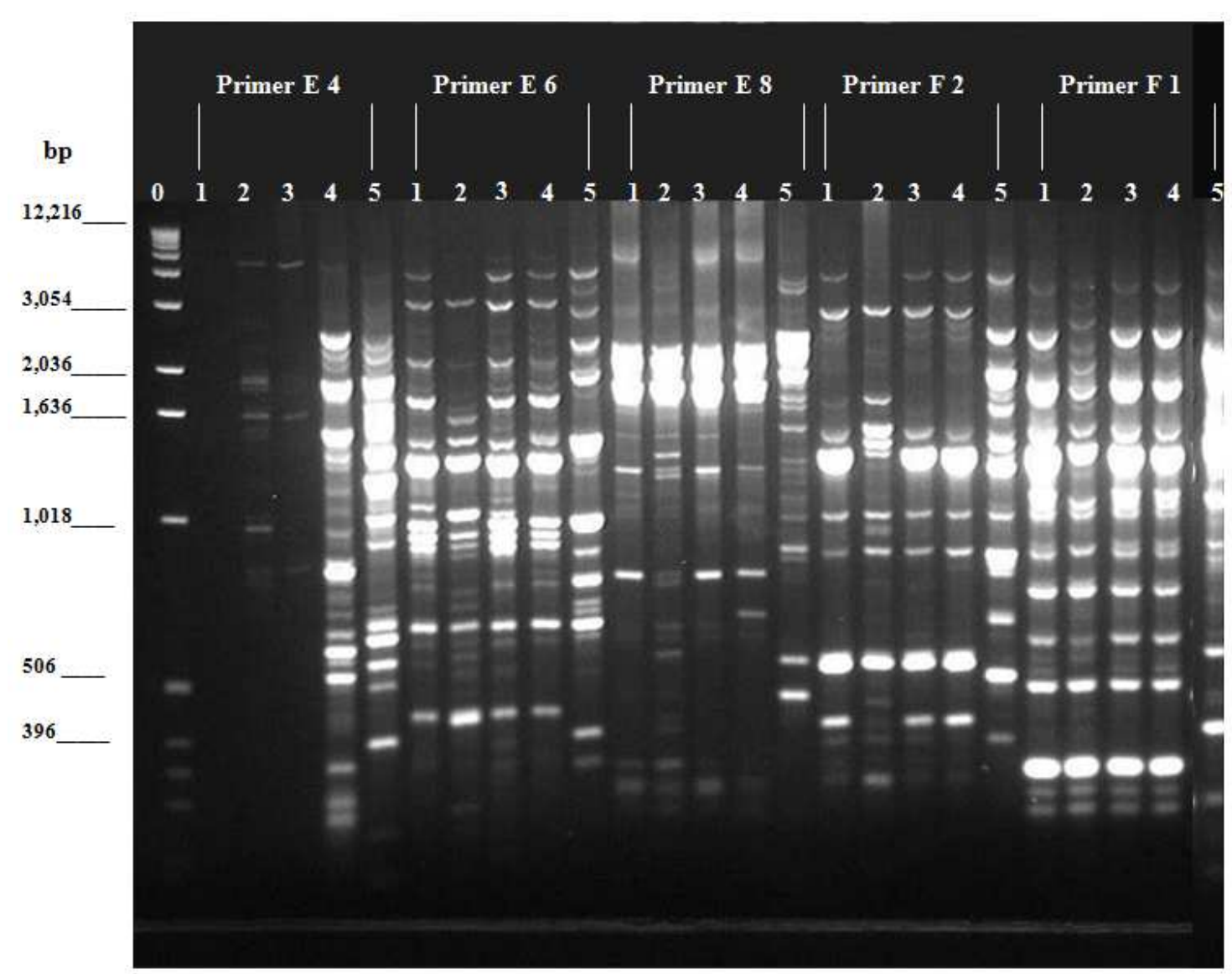

Figure 2 - RAPD-PCR comparison between brazilians and chineses Ganoderma lucidum strains. Lanes: 0, 1 kbp DNA ladder; 1, CC-22; 2, CC-63; 3, CC-144; 4, CC-157; 5, Ganoderma applanatum (included to ensure the consistency of the bands). Primers used: OPE-4, OPE-6, OPE-8, OPF-1 e OPF-2.

The results showed that both G. applanatum and G. lipsiense were more genetically distant when compared to the G. lucidum strains (Jaccard 0.371), as expected, for being strains of different species. The other G. lucidum strains remained stable, and CC-63 remained into the imprecision area. Thus, the RAPD analysis highlighted the difference between the species and could be applied to differentiating strains of the same species. Aiming to develop the genetic patterns obtained from RAPD techniques, there are only few others studies (such as the present one) dealing with G. lucidum (Hseu et al., 1996; Singh et al., 2005; Ro et al., 2007).

The major difficulty in applying this technique in studies with systematic relies on the extreme sensitivity of RAPD. Genetic profiles may suffer variations depending on the way the analysis is carried out. However, it is possible to obtain resampling results through the repetitions, once patterns start being designed through this process. There several studies on RAPD, but they converge on the fact that it would be used when a pattern was found through repetitions with strict criteria when evaluating the results (Ellsworth et al., 1993; Muralidharan and Wakeland, 1993; Leal et al., 1994; Tommerup et al., 1995; Hseu et al., 1996; Moore et al., 2001; Utomo et al., 2005; Ercisli et al., 2007; Jones et al., 2008; Kim et al., 2008). In this study, the analysis was repeated three times, until a pattern on the profile of the bands was achieved.

The observations on genetic similarity between the Brazilian and Chinese strains contributed the molecular chart of the genus Ganoderma, suggesting genetic relationship among the species 
and strains, regardless the geographical distance and allowing the use of the RAPD in basic and applied research, as well as in industry, with low costs.

\section{ACKNOWLEDGEMENTS}

This work has been supported by the Universidade Federal de Pernambuco (UFPE, Pernambuco, Brazil) and Empresa Brasileira de Pesquisas Agropecuárias (Embrapa, Brasília, Brazil).

\section{REFERENCES}

Carvalho, A. O. R. and Vieira, L. G. E. (2001), Determinação das Condições Ótimas para Análises de PCR-RAPD em Atta sexdens rubropilosa Forel (Hymenoptera: Formicidae). Neotrop. Entomol., 30, 593-600.

Chu, Q. P.; Wang, L. E.; Cui, X. Y.; Fu, H. Z.; Lin, Z. B.; Lin, S. Q. and Zhang, Y. H. (2007), Extract of Ganoderma lucidum Potentiates PentobarbitalInduced Sleep via a GABAergic Mechanism. Pharmacol. Biochem. Behav., 86, 693-698.

Colauto, N. B.; Dias, E. S.; Gimenes, M. A. and Eira, A. F. (2002), Genetic Characterization of Isolates of the Basidiomycetes Agaricus blazei by RAPD. Braz. J. Microbiol., 33, 131-133.

Del Carmen, S. J.; Largeteau-Mamoun, M. L.; Rousseau, T.; Regnault-Roger, C. and Savoie, J. M. (2002), Genetic and physiological variation in isolates of Verticillium fungicola causing dry bubble disease of the cultivated button mushroom, Agaricus bisporus, Mycol. Res., 106, 1163-1170.

Dias, L. A. S. (1998), Análises Multidimensionais. In: Alfenas, A. C. Eletroforese de Isoenzimas e Proteínas Afins: Fundamentos e Aplicações em Plantas $e$ Microrganismos. Viçosa, UFV.

Duncan, S., J. E. Barton, and P. O’Brien. (1993), Analysis of variation in isolates of Rhizoctonia solani by random amplified polymorphic DNA assay. Mycol. Res., 97, 1075-1082.

El-Mekkawy, S.; Meselhy, M. R.; Nakamura, N.; Tezuka, Y.; Hattori, M.; Kakiuchi, N.; Shimotohno, K.; Kawahata, T. and Otake, T. (1998), Anti-HIV-1 and anti-HIV-1-protease Substances from Ganoderma lucidum, Phytochemistry, 49, 1651-1657.

Ellsworth, D. L., K. D. Rittenhouse, and R. L. Honeycutt. (1993), Artifactual variation in randomly amplified polymorphic DNA banding patterns. BioTechniques, 14, 214-216.
Eo, S.K.; Kim, Y. S.; Lee, C. K. and Han, S. S. (1999), Antiherpect Activities of Various Protein Bound Polysaccarides Isolated from Ganoderma lucidum. $J$. Ethnopharmacol., 68, 129-136.

Ercisli, S.; Agar, G.; Orhan, E.; Yildirim, N. and Hizarci, Y. Interspecific variability of RAPD and fatty acid composition of some pomegranate cultivars (Punica granatum L.) growing in Southern Anatolia Region in Turkey. Biochem. System. Ecol., 35, 764769.

Ferreira, M. E. and Grattapaglia, D. (1996), Introdução ao Uso de Marcadores Moleculares em Análise Genética. Brasília: Embrapa Cenargen, 220p.

Gomes, F. C. O.; Araujo, R. A. C.; Cisalpino, P. S.; Moreira, E. S. A.; Zani, C. L. and Rosa, C. A. (2009), Comparison between Two Selected Saccharomyces cerevisiae Strains as Fermentation Starters in the Production of Traditional Cachaça. Braz. Arch. Biol. Technol., 52, 449-455.

Gonçalves, D.; Gabriel, J. E.; Madeira, H. M. F.; Schühli, G. S. and Vicente, V. A. (2010), New Method for Early Detection of two Random Amplified Polymorphic DNA (RAPD) Groups of Staphylococcus aureus causing Bovine Mastitis Infection in Paraná State, Brazil. Braz. Arch. Biol. Technol., 53, 353-360.

Grazziotin, F. and Echeverrigaray, S. (2005), Genetic Relationships Among Species of the Genus Bothrops based on RAPD Markers. Braz. Arch. Biol. Technol., 48, 359-365.

Hamelin, R. C., G. B. Ouellette, and L. Bernier. (1993), Identification of Gremmeniella abietina races with random amplified polymorphic DNA markers. Appl. Environ. Microbiol., 59, 1752-1755.

Hillis, D. M.; Moritz, C. and Mable, B. K. (1996), Molecular Systematics. Massachusetts: Sinauer Associates. 655p.

Hseu, R. S.; Wang, H. H.; Wang, H. F. and Moncalvo, J. M. (1996), Differentiation and Grouping of Isolates of the Ganoderma lucidum Complex by Random Amplified Polymorphic DNA-PCR Compared with Grouping on the Basis of Internal Transcribed Spacer Sequences. Appl. Environ. Microbiol., 62, 1354-1363.

Hse, R. S.; Moncalvo, J. M.; Wang, H. F. and Wang, H. H. (1996), Application of PCR-Amplified DNA differentiate the Ganoderma isolates. J. Chin. Agric. Chem. Soc., 34, 129-143.

Hsieh, C.; Hsu, T. and Yang, F. (2005), Production of Polysaccharides of Ganoderma lucidum (CCRC36021) by Reusing thin Stillage. Process. Biochem., 40, 909-916.

Jones, T. C.; Gemmill, C. E. C. and Pilditch, C. A. (2008), Genetic variability of New Zealand seagrass (Zostera muelleri) assessed at multiple spatial scales. Aquat. Bot., 88, 39-46. 
Kim, B. K. (1987), Pharmacological Efficacy of $G$. lucidum. Korean J. Pharmacogn., 18, 58-60.

Kim, S. W.; Kim, E. S. and Kim, Y. S. (1995), Studies on the Polysaccaride Extract from Ganoderma lucidum. J. Korean Soc. Food Nutr., 24, 147-153.

Kim, C.; Na, H. R. and Choi, H. (2008), Genetic diversity and population structure of endangered Isoetes coreana in South Korea based on RAPD analysis. Aquat. Bot., 89, 43-49.

Kindermann, J.; El-Ayouti, Y.; Samuels, G. J. and Kubicek, C. P. (1998), Phylogeny of the Genus Trichoderma Based on Sequence Analysis of the Internal Transcribed Spacer Region 1 of the rDNA Cluster. Fungal Genet. Biol., 24, 298-309.

Largeteau, M. L.; Baars, J. P. P.; Regnault-Roger, C. and Savoie, J. M. (2006), Molecular and physiological diversity among Verticillium fungicola var. fungicola. Mycol. Res., 110, 431-440

Lakshmi, B.; Ajith, T. A.; Nayana, J. and Janardhanan, K. K. (2006), Antimutagenic Activity of Methanolic Extract of Ganoderma lucidum and its Effect on Hepatic Damage caused by Benzo[a]pyrene. $J$. Ethnopharmacol., 107, 297-303.

Lan, J.; Xu, J. T. and Wang, Q. Y. (1998), Electrophoretic Studies on Esterase and Peroxidase Isozymes in Ganoderma sp. Chin. Pharm. J., 33, 1214.

Largeteau, M. L.; Baars, J. P. P.; Regnault-Roger, C. and Savoie, J. M. (2006), Molecular and Physiological Diversity among Verticillium fungicola var. fungicola. Mycol. Res., 110, 431-440.

Laroche, A., D. A. Gaudet, G. B. Schaalje, R. S. Erickson, and J. Ginns. (1995), Grouping and identification of low temperature basidiomycetes using mating, RAPD and RFLP analyses. Mycol. Res., 99, 297-310.

Leal, S. C. M., D. J. Bertioli, T. M. Butt, and J. F. Pederby. (1994), Characterization of isolates of the entomopathogenic fungus Metarhizium anisopliae by RAPD-PCR. Mycol. Res., 98, 1077-1081.

Li, X. L.; Zhou, A. G. and Li, X. M. (2007), Inhibition of Lycium barbarum Polysaccharides and Ganoderma lucidum Polysaccharides against Oxidative Injury Induced by c-irradiation in Rat Liver Mitochondria. Carbohydr. Polym., 69, 172-178.

Manly, B.F.J. (1997), Randomization, bootstrap and Monte Carlo methods in biology. Chapman \& Hall, London. 424p.

Manulis, S., L. Valinsky, A. Lichter, and D. W. Gabriel. (1994), Sensitive and specific detection of Xanthomonas campestris pv. pelargonii with DNA primers and probes identified by random amplified polymorphic DNA analysis. Appl. Environ. Microbiol., 60, 4094-4099.
Mau, J.; Lin, H. and Chen, C. (2001), Non-volatile Components of Several Medicinal Mushrooms. Food Res. Int., 34, 521-526.

Meyer, D. (1995), Árvores Evolutivas Humanas: Uma Discussão sobre Inferência Filogenética. Série Monografias, v. 3. Ribeirão Preto: Sociedade Brasileira de Genética.

Moore, A. J.; Challen, M. P.; Warner, P. J. and Elliott, T. J. RAPD discrimination of Agaricus bisporus mushroom cultivars. Appl. Microbiol. Biotechnol., 55, 742-749.

Muok, B. O.; Matsumura, A.; Ishii, T. and Odee, D. W. (2007), Genetic diversity within Sclerocarya birrea populations in Kenya. J. Arid Env., 71, 1-11.

Muralidharan, K., and E. K. Wakeland. (1993), Concentration of primer and template qualitatively affects products in random-amplified polymorphic DNA PCR. BioTechniques, 14, 362-363.

Nogami, M. (1987), Anti-allergy Activity of Ganoderma lucidum. Korean J. Pharmacogn., 18, 56-58.

Park, D. S. and Ryu, Y. J. (1996), The Genetic Relationship Analysis of Ganoderma spp. Using the PCR-RFLP and RAPD. RDA J. Agric. Sci. Biotechnol., 38, 251-260.

Qi, J. J.; Ma, R. C.; Chen, X. D. and Lan, J. (2003), Analysis of Genetic Variation in Ganoderma lucidum after Space Flight. Adv. Space Res., 31, 1617-1622.

Raeder, U. and Broda, P. (1985), Rapid Preparation of DNA from Filamentous Fungi. Lett. Appl. Microbiol. 1, 17-20.

Rajwana, I. A,; Tabbasam, N.; Malik, A. U.; Malik, S. A.; Rahman, M. and Zafar, Y. (2008), Assessment of genetic diversity among mango (Mangifera indica L.) genotypes using RAPD markers. Sci. Hort., 117, 297-301.

Ro, H.; Kim, S. S.; Ryu, J. S.; Jeon, C.; Lee, T. S. and Lee, H. (2007), Comparative Studies on the Diversity of the Edible Mushroom Pleurotus eringii: ITS Sequence Analysis, RAPD Fingerprinting, and Physiological Characteristics. Mycol. Res., 111, 710715.

Singh, S. K.; Rai, R. D. and Kamal, S. (2005), Molecular Identification of Some Medicinally Important Aphyllophorales Mushrooms Based on ITS rDNA Sequences and RAPD data. Int. J. Med. Mushr., 7, 565-572.

Solouki, M.; Mehdikhani, H.; Zeinali, H. and Emamjomeh, A. A. (2008), Study of genetic diversity in Chamomile (Matricaria chamomilla) based on morphological traits and molecular markers. Sci. Hort., 117, 281-287. 
Stringari, D.; Glienke, C.; Christo, D.; Maccheroni Jr, W. and Azevedo, J. L. (2009), High Molecular Diversity of the Fungus Guignardia citricarpa and Guignardia mangiferae and New Primers for the Diagnosis of the Citrus Black Spot. Braz. Arch. Biol. Technol., 52, 1063-1073.

Tang, C. H.; Zhang, J. S.; Chen, M. J.; Tan, Q.; Cao, H.; Xu, W. and Pan, Y. J. (2005), Preliminary Study on Genetic Diversity among Ten Strains of Ganoderma. J. Nanjing Agric. Univ., 28, 133-136.

Tang, W.; Liu, J. W.; Zhao, W. M.; Wei, D. Z. and Zhong, J. J. (2006), Ganoderic Acid T from Ganoderma lucidum Mycelia Induces Mitochondria Mediated Apoptosis in Lung Cancer Cells. Life Sci., 80, 205-211.

Tang, S.; Li, Y.; Geng, Y.; Zhang, G.; Wang, L. and Zhong, Y. (2007), Clonal and spatial genetic structure in natural populations of Luohanguo (Siraitia grosvenorii), an economic species endemic to South China, as revealed by RAPD markers. Biochem. System. Ecol., 35, 557-565.

Tommerup, I. C.; Barton, J. E. and O'Brien P. A. (1995), Reliability of RAPD fingerprinting of three basidiomycete fungi, Laccaria, Hydnangium and Rhizoctonia. Mycol. Res., 99, 179-186.

Tsivelikas, A. L.; Koutita, O.; Anastasiadou, A.; Skaracis, G. N.; Traka-Mavrona, E. and KoutsikaSotiriou, M. (2009), Description and Analysis of Genetic Diversity among Squash Accessions. Braz. Arch. Biol. Technol., 52, 271-283.

Utomo, C.; Werner, S.; Niepold, F. and Deising, H. B. (2005) Identification of Ganoderma, the causal agent of basal stem rot disease in oil palm using a molecular method. Mycopathologia, 159, 159-170.

Venkatachalam, L.; Sreedhar, R. V. and Bhagyalakshmi, N. (2008), The use of genetic markers for detecting DNA polymorphism, genotype identification and phylogenetic relationships among banana cultivars. Mol. Phyl. Evo., 47, 974-985.
Wang, S. Z.; Bai, C.; Fan, J.; Gao, Y.; Yang, J. F. and Yang, Y. J. (2003), A Study on the RAPD Analysis of Ganoderma lucidum and Pleurotus ostreatus Protoplast Fusant Genome. Acta Edulis Fungi, 10,15.

Wasser, S. P. and Weis, A. L. (1999), Therapeutic Effects of Substances Occurring in Higher Basidiomycetes Mushrooms: A Modern Perspective. Crit. Rev. Immunol., 19, 65-96.

Weir, B. W. (1990), Genetic Data Analysis: Methods for Discrete Population Genetic Data. Sunderland: Sinauer. 445p.

Williams, J. G. K.; Kubelic, A. R.; Livak, K. J.; Rafalski, J. A. and Tingey, S. V. (1990), DNA Polymorphisms Amplified by Arbitrary Primers are Usefull as Genetic Markers. Nucleic Acids Res., 18, 6531-6535.

Zakaria, L.; Kulaveraasingham, H.; Guan, T. S.; Abdullah, F. and Wan, H. Y. (2005), Random Amplified Polymorphic DNA (RAPD) and Random Amplified Microsatellite (RAMS) of Ganoderma from Infected Oil Palm and Coconut Stumps in Malaysia. Asia Pac. J. Mol. Biol. Biotechnol., 13, 2324.

Zheng L, Jia, D.; Fei, X.; Luo, X. and Yang, Z. (2007), An Assessment of the Genetic Diversity within Ganoderma Strains with AFLP and ITS PCR-RFLP. Microbiol. Res., doi:10.1016/j.micres.2007.02.002

Zhu, X. L.; Chen, A. F. and Lin, Z. B. (2007), Ganoderma lucidum Polysaccharides Enhance the Function of Immunological Effector Cells in Immunosuppressed Mice. J. Ethnopharmacol., 111, 219-226.
Received: November 23, 2009; Revised: May 11, 2010; Accepted: November 11, 2010. 